\title{
A brief look at automation activities in Turkish university libraries
}

\section{YASAR TONTA}

\section{Introduction}

Turkey, one of the cradles of civilisation, is a republic founded by Kemal Ataturk in 1923 after the collapse of the 600-year-old Ottoman Empire. Its location in two continents (Europe and Asia) has been a central factor in its history, culture and politics; Turkey has often been called a bridge between East and West. Turkey, Islamic in tradition, is a newly industrialised democratic nation of 55 million people.

In Turkey, there are 29 universities (28 state and one private). They are governed by a common law, namely the Higher Education Act. The majority of universities have decentralised libraries, which is largely due to the fact that there has been no legislation or by-laws that specifically govern the establishment and organisation of libraries within a university.

The importance of computers for library and information centres has long been recognised in Turkey. The history of computer use goes back to the early 1970s when university libraries started to use computers mainly for 'batch' jobs, such as the production of a union catalogue of serials, acquisition lists and the like. In a recent survey it was shown that almost all university libraries have a strong interest in automation'. Some have been planning to computerise their operations, whilst others are considering this option seriously. The existing computer use in university libraries is heavily centred in the following operations: union lists of serials and books, circulation control, acquisition, cataloguing and current awareness.

\section{Housekeeping systems}

The University of Hacettepe Library in Ankara was the first to develop and experiment with a real-time circulation control system for books and serials between 1973 and 1974. The project was, unfortunately, discontinued in view of other priorities. After a considerable lapse, the University decided to set up an integrated system. Taking into account their previous experience, project leaders at Hacettepe started to work carefully on setting up a system. Issues, such as standardisation of technical services, possibility of working within a network environment, ease of use, and information retrieval capability of the system became of primary concern. Implementing a systems analysis took nine months. The project leaders first concentrated on the circulation module which is based on an inventory control system, and then decided to gradually develop

Program, vol. 24 no. 1, January 1990, pp. 73-80. 
other modules. So far the software comprises some 22,000 lines of COBOL on a Data General Desk Top $30^{2}$.

The Middle East Technical University (METU) in Ankara is well-equipped with a wide variety of computing facilities. For years, the METU Library has been connected to the mainframe computer of the University via a terminal, which is used for serials and circulation control. Despite the technology and expertise that is available within the University, it seems that the Library is rather slow in bringing about some changes in collaboration with other departments.

The Bilkent University Library is the first to buy US MARC records on CD-ROM from BiblioFile which it uses for copy cataloguing of books in its collection. The Library has been downloading the bibliographic records from CD-ROMs on to the computer, using software developed by the university's computer centre. Bilkent is a newly established private university and so the library has no serious problem of retrospective conversion. The Library keeps a card catalogue; the number of items in its collection is somewhere between 15,000 and 20,000 . It is in a very good position to build a machine-readable database from the very beginning if it is able to implement the computer-based system in a short period of time, and start downloading catalogue records from CD-ROMs directly on to the online catalogue.

So far the only university library that has been able to implement a circulation control system and actually put it into operation is the Bosporus University Library in Istanbul. The Library is in the process of converting its bibliographic records into machine-readable form, and is working on other modules. The computer printout of its serials list is also published (albeit irregularly).

The University of Anatolia Library has been using dBase III Plus in order to automate its operations; this system is perhaps the first microcomputer-based library system in Turkey, and it includes cataloguing, circulation, acquisition, data retrieval, production of barcode labels for books and user cards, etc. It seems however that the limitations of microcomputers have not been taken into account during the design process. In part, this may be due to the fact that the Library is contemplating upgrading the system to the mainframe computer of the University.

\section{Telecommunications in Turkey}

The General Directorate of the Post, Telegram and Telephone (PTT) is the highest authority for setting up and operation of all public telecommunication facilities within Turkey, and data transmission over leased lines was realised for the first time in 1976-1977. As computer applications in various organisations have gradually grown, the number of leased lines has also mushroomed. Until 1984, telecommunications were conducted only over analogue telephone exchanges. In 1984, the first digital telephone exchange was put into service in Ankara. Ever since, a considerable amount of effort 
has been put into the projects involving digital telephone exchange, and today the network covers most of the cities and townships of the country.

In 1986, subscribers were eventually allowed to transmit data over the automatic telephone network. An experimental packet switching data network became operational in 1987. TELENET, one of the American packet switching data networks, is accessible via satellite connection thus providing access to online search services and to the packet-switched networks of other countries connected to TELENET. An electronic mail system, and services such as telefacsimile, teletex and videotex are also operational. A pilot project on Integrated Services Digital Network (ISDN) was started two years ago, and it is believed that the infrastructure of Turkish data communication network is capable of coping with the transformation. There has been enormous progress in telecommunication services in Turkey in recent years, though this is insufficient to satisfy the potential demands. More funds need to be allocated and more research projects need to be supported in order to reach international standards.

\section{Networking studies in Turkish university libraries}

In 1986, the Turkish Network of Universities and Research Institutions (TUVAKA) was set up and universities were able to connect to the European Academic and Research Network (EARN) via Pisa in Italy. EARN is a computer network designed to create a sufficient infrastructure for communications between universities and academic research institutions in Europe. EARN also has a connection to its American counterpart BITNET. At the present time, some 17 universities in Turkey belong to the TUVAKA network as their computers are compatible with those of EARN. A thorough investigation is required of the ways in which Turkish universities can avail themselves of the services of EARN and other networks; for instance by communicating with other universities and research institutions, including libraries, in order to share documents, programs and data, and work together on common projects.

The setting up of TUVAKA has resulted in considerable attention to automation in university libraries, particularly from computer scientists affiliated with TUVAKA. Some believed that libraries could easily be interconnected, and the procurement of an integrated library system for all university libraries could solve the overall problems. Few people seemed to be aware of the requirements for such an undertaking however. Lack of standardisation of cataloguing and technical services, non-existence of a utility that would provide machine-readable bibliographic records, different codes used by different libraries, lack of trained staff and technical personnel in libraries, the lack of funds, and so on, were all seen as trivial matters and unfortunately the views of librarians and information professionals have not yet been sought. 


\section{Online searching}

Because of financial considerations, individual university libraries have no access to online bibliographic databases available from such vendors as Dialog, ESA-IRS and BRS. However these services are available through the Higher Education Council Documentation Center (HECDOC) and the Information Retrieval System of the Turkish Scientific and Technical Research Center (TUBES) ${ }^{3}$. HECDOC has been involved in all kinds of activities concerning university library services, and it performs about 5,000 off-site online searches every year for researchers in universities. Its core collection of serials (comprising nearly 15,000 titles), is used to provide the full text of documents retrieved through online searches. In fact, the Centre automatically sends the copies of articles to the requester from its own collection. TUBES also performs online bibliographic searches for academia. The great majority of its search requests ( 85 per cent) come from universities. The number of searches that TUBES performs is in the range of 2,500 to 3,500 per year.

Some large university libraries are considering having online access to the serials subscription information held by such subscription agencies as Ebsco and Faxon. By so doing, some of them may well decide to buy stand alone serials control systems marketed by these vendors as they tend to offer substantial discounts.

\section{Recommendations}

\subsection{Need for an authoritative council or committee}

Most of the university libraries in Turkey seem to be unfamiliar and unaware of the potential pitfalls and dangers of developing computer-based library and information systems. They tend to think that the procurement of a computer will heal all wounds. Yet when they acquire one they immediately realise that something has to be done in order to make it useful.

With a few exceptions, almost all university libraries consider the option of developing a system from scratch first. One of the reasons for this is that there is no indigenous commercially available software package that is specifically designed for university libraries. Since the choices before librarians are limited, they always think of developing an inhouse system for themselves in collaboration with the computer centre of the university. Anyone who has gone through this painful process will be well aware of the hardships involved. Developing a module, not to mention a fully-fledged integrated system, may take several years. Even then, there is no guarantee that the end-product is going to be free of 'bugs'. Moreover, in the Turkish case, neither university libraries nor outside organisations or companies have enough experience and expertise in developing a computerised system for libraries. There is a saying, "the road to library automation is strewn with the corpses of librarians, systems analysts and computer specialists". The question is whether we can afford to have such 
a high number of casualties since those professionals are already scarce in Turkey. Also, the lack of an authoritative council or any other body at national level which would include specialists from such areas as library and information studies, computer science and telecommunications, hinders the efforts of individual university libraries in this respect; such a council or committee, supported by the government and universities, should be set up to study a wide range of issues concerning automation of university libraries.

\subsection{More funds}

The problems impeding the use of computers in the majority of university libraries are mainly related to lack of funds. At present, some university libraries get a share of as little as one or two percent of the general university budgets. This is hardly enough for the acquisition of library materials, let alone computer technology which is usually quite expensive. The effects of the 'micro revolution', which has completely changed the image of the computer and computer use since the beginning of the 1980 s, are yet to be fully felt in Turkey. This is not to say that no library can afford to buy a turnkey system from abroad, but it should be borne in mind that not only have most of these systems been designed for different kinds of needs than those of Turkish university libraries, but also the language barrier is hard to overcome when it comes to running the system on a daily basis. In general, vendors of such systems are reluctant to make any changes in their products without any financial justification.

Standardisation of library operations and technical services is an area which has been neglected so far. There has been no such thing as a utility or an efficient national library system that is able to hold the machine-readable records of all library materials published in Turkey, enabling university libraries to cut the costs of cataloguing and classification and allowing them to share data. Full financial support should be given to the existing modest automation projects of university libraries. Computer centres of the universities should be encouraged to co-operate with libraries in developing library systems and/or adapting the existing ones.

\subsection{Increase of qualified librarians and technical staff}

Constant shortage of professionally qualified librarians, associated with a low status of librarians and low priority for libraries, have been important and chronic problems. Apart from the fact that there is a limited number of qualified librarians who have enough experience in library automation, the number of computer specialists who have adequate familiarity with library applications is also very limited. Needless to say, this has paramount impact upon the success of a library automation project. Unfortunately, because of the dearth of professionals, it is not possible to support even existing computer facilities to which libraries may have access. The status of librarians and information professionals is rather low in regards to salary scale, promotion, and in relation to other professions in general, as well as in the organisation or institution of which the library is a part. 


\subsection{Improved education for librarianship and information studies}

Education for librarianship in Turkey is given both at undergraduate and graduate levels, and it is mainly traditional. Library schools have yet to benefit from information technology. So far none of the existing three library schools has been able to incorporate information technology into its curriculum. Faculty and students are totally dependent on mainframe computers of the universities for courses on programming, library automation and so on. The lack of appropriate technology in library schools has been one of the major problems which in turn affects the automation activities of libraries. Interdisciplinary features of automation studies cannot be taught efficiently and effectively without such facilities. Theoretical courses in this respect tend to be not very successful unless supported with 'hands-on' computer practice. It seems that small microcomputer systems with suitable software for library schools may be much more useful and handy. Such systems would provide flexibility and convenience for teaching aims, or, at least, on-site terminals connected to the mainframe computer of the university would be beneficial ${ }^{4}$.

Given the existing facilities of library schools, it is obvious that graduates are more prepared for traditional library posts than, say, for emerging information professions or for technically oriented jobs like designing and implementing computer-based information systems, information management and the like. Yet it appears that the market would soon require more of the second type of librarians equipped with the knowledge of non-traditional library and information services. The time has come for Turkish library schools to review and revise their curricula so as to keep up with the recent developments and changes in the profession. Library schools should offer more promising programmes emphasising the use of information technology and computers in libraries and information centres, information systems design, information management, online searching, and so on.

Continuing education of librarians and information specialists should also be considered. Seminars, workshops and short courses on issues such as networking, online searching, microcomputer use in libraries, make professionals aware of the potential use of computers in their units. Recent attempts along these lines by the Department of Library Science of Hacettepe University and HECDOC are worth mentioning in this respect.

\subsection{International co-operation}

International aid and assistance have played an essential role in the establishment of modern university libraries in Turkey. Of the centralised university libraries mentioned, the METU, the Universities of Bosporus and Hacettepe were created and organised along the lines of the American university library system, with the help of international organisations such as Unesco, the Ford Foundation, the Agency for International Development (AID), and others ${ }^{5}$. Turkey has always welcomed and enjoyed the contributions of international colleagues. Mutual professional visits, short- or long-term attachments of 
educators in Turkish library schools, education and training of Turkish librarians abroad have actually increased in the past several years.

The endeavours of the Medical College of Wisconsin Libraries regarding the education and training of Turkish medical librarians; the education of librarians in the US and Britain; Fulbright Scholarships and US Book Fellowship programmes; the co-operation between the British Council and the Turkish library schools; are all excellent examples of co-operation and mutual understanding on the international level and it is hoped that these programmes will continue and can expand in the future.

\section{Acknowledgement}

I would like to thank Mr Mario Guzman for his thoughtful comments on the first draft of this paper.

(C) Aslib and Yasar Tonta

\section{References}

1. Y. Tonta. Turkish university libraries. Libri, vol. 37, no. 2, December 1987, pp. 259-278.

2. H. Tunckanat, et al. Bilgieris: Hacettepe University Medical Center Library Automation Project. (In Turkish). Bulletin of Turkish Librarianship, vol. 2, no. 3, 1988, pp. 109-116.

3. For more information about the services of the HECDOC, see: $N$. Tuncer. Experience with on-line search in Turkey. International Library Review, vol. 19, 1987, pp. 175-178.

4. Y. Tonta. Recent developments in education for librarianship. (In Turkish) In: Turkish Librarianship 1987. Ankara: KTB, 1987.

5. R.B. Downs. Library developments in Turkish universities. Pakistan Library Bulletin, vol. 4, September-December 1971, pp. 9-13.

\section{Further reading}

1. P.W. Brennen, M.B. Blackwelder, and M. Kirkali. Perspectives in medical school library services in Turkey. Bulletin of the Medical Library Association, vol. 75, no. 3, July 1987, pp. 239-244.

2. I. Kum and P.L. Erdogan. Turkish library developments. Unesco Joumal of Information Science Librarianship and Archives Administration, vol. 2, October-December 1980, pp. 252-256.

3. K. Kurosman. The academic library in Turkey. International Library Review, vol. 12, 1980, pp. 173-200.

4. M.J. Scepanski. Turkish librarianship amidst conflict and change. Leads, vol. 25, Summer 1983, pp. 6-8.

5. Y. Tonta. Interlending services in Turkish university libraries. Interlending and Document Supply, vol. 15, no. 4, October 1987, pp. 122-125. 
6. Y. Tonta. Turkish librarianship: an annotated bibliography (1950-1984). International Library Review, vol. 18, no. 4, 1986, pp. 317-326.

\section{Author}

Yasar Tonta, Hacettepe University, Department of Library Science, Beytepe, Ankara, Turkey.

Note. This communication is based on a presentation given at the Fifth National Conference of the Association of College and Research Libraries, 5-8 April 1989, Cincinnati, Ohio. 